\title{
Distribution of SDF1-3'A polymorphisms in three different ethnic groups from Brazil
}

\begin{abstract}
A mutation described as a G-to-A transition has been reported in SDF-1 gene (SDF1-3'A), being prevalent in all ethnic groups, except in Africans. This mutation is associated with the onset of AIDS progression. Our aim was to identify the frequency of this allele in different groups from Brazil: Tiriyó and Waiampi Amerindian tribes (Asian ancestry); selected blood donors from Joinville (German descendents); and from Salvador (predominance of African and Portuguese mixture). SDF1-3'A was screened by PCR/RFLP with MspI enzyme. Our results showed a high allelic frequency in Tiriyó tribe (0.24) and Joinville population (0.21), and a frequency of 0.17 and 0.05 in the Salvador population and in the Waiampi tribe, respectively. There was no statistical difference among the allelic frequencies in the studied ethnic groups, except in the Waiampi. Due to the great genetic diversity among Brazilian population and the lack of studies on SDF1-3'A allele, our study of this allelic frequency in these different Brazilian ethnic groups could be important to identification of biomarker for therapeutic support in progression to AIDS and a molecular marker for analysis of evolutionary relationships among human populations.
\end{abstract}

Keywords: SDF1-3'A polymorphism; brazilian population; HIV-1 co-receptor.

[Braz J Infect Dis 2010;14(2):197-200] CElsevier Editora Ltda.

\section{INTRODUCTION}

Human genetic diversity is determined by biological and demographic factors and has essential implications for understanding the genetic basis of illnesses. Mutations may have important effects that should be studied because they may present opportunities to develop better strategies against some disease.

Since the chemokine receptor and ligands were identified, several reports have been published showing the relationship between mutations in chemokines and their receptors gene and the susceptibility to HIV-1 infection or progression to AIDS..$^{1-3}$

CCR5 has been described as a major HIV-1 co-receptor, and the correlation between 32 base pair deletion in CCR5 gene (CCR5- $\triangle 32)$ and R5 HIV-1 infection susceptibility has been observed. ${ }^{4,5}$

Some other co-receptors to HIV-1 have been identified, as well as the Stromal-Derived Factor 1 (SDF-1/CXCL12), which is the principal ligand for CXCR4, the HIV-1 co-receptor for $\mathrm{T}$ lymphocyte cells. A transition at position
801 ( $G$ to A), SDF1-3'A, was described as a common polymorphism in the $3^{\prime}$ untranslated region of the gene. It is not yet clear if the homozygous SDF1-3'A mutation genotypes does associated with an increase or decrease in the progression to AIDS and/or with protection against infection. ${ }^{6,7}$ In pediatric AIDS, for example, it has been suggested that the protective effect of CCR5- $\triangle 32$ appears to be abrogated by the SDF1-3A genotype. ${ }^{8}$

In fact, the frequencies of the SDF1-3'A allele were analyzed in cohorts of HIV-1 infected and non-infected individuals. These data together have reported a delayed progression to AIDS, and no correlation to a diminished susceptibility to HIV-1 infection. ${ }^{9,10}$ Although the host genetic factors have become an important matter in HIV/AIDS research, so far there are rare reports about the frequency of this host positive populations from Brazil.

Worldwide population surveys have shown that the prevalence of the $3^{\prime} \mathrm{A}$ mutation varies significantly in some ethnical groups and that the allelic frequencies are correlated with gepolymorphism among uninfected and HIV-1
Authors

Rogerio Grimaldi ${ }^{1,2}$

Acosta $\mathrm{AX}^{1,3}$

Machado TMB

Bomfim TF

Galvão-Castro B ${ }^{1,2}$

${ }^{1}$ Laboratório Avançado de Saúde Pública, Centro de

Pesquisas Gonçalo Moniz FIOCRUZ.

${ }^{2}$ Escola Bahiana de

Medicina e Saúde

Pública / Fundação para

o Desenvolvimento das

Ciências.

${ }^{3}$ Universidade Federal da Bahia, Faculdade de Medicina, Department of Pediatrics. (Salvador-BahiaBrazil).

Submitted on: 03/10/2009 Approved on: 12/10/2009

Correspondence to: Rogerio Grimaldi Laboratório Avançado de Saúde Pública Centro de Pesquisas Gonçalo Moniz FIOCRUZ Rua Waldemar Falcão, 121, Candeal Salvador - BA - Brazil CEP: 40296-710 E-mail: grimaldi@bahia. fiocruz.br

We declare no conflicts of interest 
netic backgrounds and geographical regions. The SDF1-3'A allelic frequency has been most frequently found in Asian and Caucasian (0.26 and 0.21, respectively), in Hispanic populations (0.16), and lower in African (0.06). ${ }^{9}$

Analyses of biomarkers at human autosomic chromosomal have shown a geographical structuring of ethnical groups at molecular level ${ }^{11,12}$ and propose that a undersized group migrated out of East Africa and their descendents have expanded to most of the current population. ${ }^{13}$

To evaluate different human populations, specific biomarkers have been an effective approach for support in targeted therapy for AIDS, as well as to survey population ancestry. Thus far, an association has been observed for susceptibility to AIDS progression and SDF1-3'A allele. Polymorphisms of various genes like CCR5- $\triangle 32$, CCR2-64I, and SDF1-3'A have been associated with disease development and, together with others, it has been suggested that they could be used as biomarker.

Considering that HIV/AIDS epidemic is a serious public health matter in Brazil, and the paramount importance to obtain a better knowledge of population genetic background in this country as well as the influence of diverse polymorphisms on progression to AIDS, we investigate the allelic frequency of 3'A allele in three different Brazilian ethnical groups.

\section{MATERIAL AND METHODS}

\section{Study population}

We studied a total of 565 individuals from different Brazilian ethnic groups, including randomly selected individuals from sentinel surveillance areas from Salvador $\left(13^{\circ} \mathrm{S} ; 38^{\circ} 3112 \mathrm{~W}\right)$ (mixed African and Portuguese descendent), selected blood donors from Joinville $\left(26^{\circ} 18 \mathrm{~S} ; 48^{\circ} 50 \mathrm{~W}\right)$ derived from a cohort of Germany descendents (European ancestry), and Amerindians isolated tribes of Tiriyó $\left(3^{\circ} 30 \mathrm{~S} ; 53^{\circ} 21 \mathrm{~W}\right)$ and Waiampi (Asian ancestries) from the Amazon River basin (North region). All participants were negative for HIV-1 infection, and samples were collected with the informed consent signed by participants. The project was approved by the Research Ethics Committee of Centro de Pesquisas Gonçalo Moniz (CPqGM/FIOCRUZ).

Salvador, Bahia: Salvador, the capital of Bahia state, is located in the Northeast region of Brazil. Roughly $80 \%$ of the city's 2.5 million inhabitants ${ }^{14}$ are black or mixed race descendants of Africans and Portuguese. ${ }^{15} \mathrm{~A}$ cross-sectional study population was randomly selected from sentinel surveillance areas previously established for the investigation of various infectious diseases. ${ }^{16}$ This population was comprised of $38.6 \%$ males and $61.4 \%$ females. Mean age was 22.1 for males and 29.3 for females.

Joinville, Santa Catarina: Joinville is located in the South region of Brazil. Its population of approximately 430,000 in- habitants is mainly of European descendants. ${ }^{14}$ Selected German descendants blood donors (b.d.) were studied - $88 \%$ were male and $12 \%$ were female, with an age distribution of 18 to 60 (average 39) years and 19 to 42 (average 29) years, respectively. They had no reported risk behavior for sexually transmitted diseases.

Brazilian Amerindian populations: Samples from two Amerindian tribes (Tiriyó and Waiampi) individuals located in the Amazon River Basin (North region) were analyzed in the present study. The Tiriyó tribe speaks the Caribe language and inhabits a reserve on the Suriname-Brazil frontier: 750 of its 1,700 individuals live in Brazil. The Waiampi tribe speaks Tupi-Guarani and lives on a reserve on the French Guiana-Brazil frontier: 450 of its 1,200 individuals live in the Brazilian state of Amapá.

\section{Laboratorial procedure}

Blood samples were collected from the studied groups during different time periods: from the Amerindian tribes, between April-May 1997; from Salvador individuals of the sentinel surveillance areas, between April-August 1998; and from German descendents b.d. of Joinville, between November 2000 and January 2001.

Ten milliliters of whole blood were collected from each individual, using ethylene-diamine tetra acetic acid (EDTA) as anticoagulant. All samples were collected with participants' informed consent.

DNA was extracted from peripheral blood mononuclear cells (PBMCs), and whole blood using the DNAzol commercial kit (GIBCO-BRL, Rockville, USA). PCR was performed in a Perkin-Elmer 9600 thermal cycler (Perkin-Elmer, Connecticut, USA) using 100-200 Ng of DNA.

\section{SDF-1 analysis by PCR}

The SDF-1 3'UTR gene was amplified by PCR containing $1.25 \mathrm{mM}$ dNTPs, $20 \mathrm{mM} \mathrm{MgCl} 2$ PCR buffer, 2.5 pmoles for each of the following primers: 5'-CAGTCAACCTGGGCAAAGCC-3' and '3'-AGCTTTGGTCCTGAGAGTCC-5', and $1 \mathrm{U}$ Taq DNA polimerase in a $25 \mu \mathrm{L}$ final volume; 35 cycles were performed, consisting of $30^{\prime \prime}$ at $95^{\circ}$ $\mathrm{C}, 1^{\prime}$ at $58^{\circ} \mathrm{C}$ and $30^{\prime \prime}$ at $72^{\circ} \mathrm{C}$ with a final extension of $10^{\prime}$ at $72^{\circ} \mathrm{C}$ (Winkler et al. 1998). ${ }^{9}$

\section{SDF1 genotyping}

MspI 5U restriction enzyme (BioLabs inc., New England) was used to digest the PCR products in a final volume of $20 \mu \mathrm{L}$ and incubated during 3 hours at $37^{\circ} \mathrm{C}$ and then subjected to $2 \%$ agarose gel electrophoresis. The fragments were visualized by ethidium bromide staining and UV fluorescence. SDF-1 wild-type (SDF-1/SDF-1), heterozygous (SDF$\left.1 / 3^{\prime} \mathrm{A}\right)$, and homozygous to $3^{\prime} \mathrm{A}$ allele (3'A/3'A) genotypes were detected by the presence of bands with $202 \mathrm{bp}$ and 100 bp, 302 bp, 202 bp and 100 bp, and single band of 302 bp, respectively. Ambiguous results were resolved by performing 
electrophoresis of products of enzyme restriction in a $10 \%$ acrylamide gel, and the gel stained with silver. The images of the gel were captured and recorded with the Eagle Eye Imaging System (Stratagene, USA).

\section{Statistical analysis}

A database with the results was set up using Epi Info software version $6.04 \mathrm{~d}$. Genotypic and allelic frequencies were estimated and compared by Gene counting method between the groups. Conformity with Hardy-Weinberg equilibrium of genotypic frequencies was tested and heterogeneity among population samples was evaluated using $\chi 2$ test. Differences between groups were considered to be statistically significant when $\mathrm{p}<0.05$.

\section{RESULTS}

We analyzed the frequency of SDF1-3'A in three different ethnic groups from distinct Brazilian geographic regions. The differences observed were not statistically significant when we compared the allelic frequencies found $(p>0,005)$, except in Waiampi tribe. Interestingly, SDF1-3'A frequency was highest in Tiriyó and lowest in Waiampi Indigenous groups ( 0.24 and 0.05 , respectively); and as expected, 0.21 in Joinville's blood donors and 0.17 in Salvador's inhabitants. Table 1 summarizes the mutation distribution in different genotypes of SDF-1 gene in the studied groups. No statistical difference from Hardy-Weinberg equilibrium for frequency distribution was found.

\section{DISCUSSION}

The CCR5- $\triangle 32$, CCR2-64I and SDF1-3'A polymorphisms are three of the main host factors to protect against HIV-1 infection and/or AIDS progression. It is currently admitted that the $32 \mathrm{bp}$ deletion in the gene codifying CCR5 protein is the most evident host mutation related with HIV-1 illness. ${ }^{3}$ Studies on the CCR2-64I mutation showed that, even in heterozygotes, an increased AIDS-free survival was observed. ${ }^{17}$ The controversy still remains about the SDF1-3'A effect on disease progression and viral entry in host cell. ${ }^{9,2,18,7,19}$
A few studies have demonstrated a low frequency of SDF1-3'A in the general Brazilian population. ${ }^{20,21}$ In this work we showed that the SDF1-3'A allele was found in all studied ethnic groups, corroborating previous studies. ${ }^{9,21}$ The highest SDF1-3'A allele prevalence observed in Tiriyó tribe (0.21) and Joinville population (0.24) (Asian and Caucasian ancestries, respectively), confirm early studies showing a higher frequency in Asian and Caucasian descendants (approximately 0.26 and 0.21 , respectively) and a lower frequency in African descendents (0.06). ${ }^{9}$ Interestingly, the Waiampi tribe presented a notably lower frequency (0.05) than that of the Tiriyo tribe (0.21), showing that the inter-tribe diversity is greater than that found among different ethnicities. Although Tiriyó and Waiampi tribes are descendents of a single ancestral group, ${ }^{22,23}$ they demonstrated that the frequency of the $\beta$-globin gene haplotypes was lower and there were low levels of heterozygosity and intrapopulational differentiation. There was a single clearly predominant haplotype in most tribes, including the Waiampi, but those of the Tiriyó presented no less than four haplotypes with relatively high frequencies, suggesting that the genetic distances between Brazilian Amerindians are low, except for the Tiriyó tribe. There is general agreement that the Native American founder populations migrated from Asia into America through the Bering Strait. ${ }^{24}$ We observed that Waiampi tribe presented a lower frequency than that found for Tiriyó tribe. This could be explained by some evolutionary forces, such as the founder effect, as well as by a genetic drift, and the most important factor, the interethnic admixture, which could change gene frequencies. Nevertheless, genetic analyses in Brazilian Amerindians have shown that, while the number of heterozygous and alleles are low, there is a clear heterogeneity among tribes, showing a diversity of allelic distribution models. This fact suggests that comparative analyses survey of an undersized number of Amerindian groups may not sufficiently represent the entire variety of genetic variability in Brazilian Amerindians. ${ }^{25}$

When we analyzed the genotype distribution (Table I), we observed that Salvador (with its high number of African descendents), Joinville (Germany descendents), and Tiriyó (Amerindian) populations are homogenous $(\mathrm{p}=0.1285)$. The inclusion of the Waiampi group engendered extremely significant heterogeneity $(\mathrm{p}=0.0001)$.

Table 1. Distribution of SDF1-3'A allele and genotype frequencies in three studied Brazilian ethnical groups

\begin{tabular}{|c|c|c|c|c|c|c|c|c|}
\hline \multirow{2}{*}{$\begin{array}{l}\text { Population/ } \\
\text { ascendency }\end{array}$} & \multirow[t]{2}{*}{ Ethnical group } & \multirow[t]{2}{*}{$\mathbf{n}$} & \multicolumn{3}{|c|}{ Genotypes } & \multirow{2}{*}{$\begin{array}{c}\text { Allelic } \\
\text { Frequency }\end{array}$} & \multirow[t]{2}{*}{$\chi^{2}$} & \multirow[t]{2}{*}{ p-value } \\
\hline & & & $\begin{array}{c}\text { SDF-1/SDF-1 } \\
\text { n (\%) }\end{array}$ & $\begin{array}{c}\text { SDF-1/3'A } \\
\text { n (\%) }\end{array}$ & $\begin{array}{c}\text { 3'A/3'A } \\
\text { n (\%) }\end{array}$ & & & \\
\hline Salvador/African & Afro-Brazilian & 215 & $151(70.2)$ & $57(26.5)$ & $7(3.3)$ & 0.17 & 0.264 & $0.80<\mathrm{p}<0.90$ \\
\hline Joinville/German & Caucasian & 93 & $58(62.4)$ & $31(33.3)$ & $4(4.3)$ & 0.21 & 0,002 & $\mathrm{p}>0.95$ \\
\hline Tiriyó/Asian & Amerindian & 179 & $108(60.4)$ & 57 (31.8) & $14(7.8)$ & 0.24 & 2.589 & $0.20<\mathrm{p}<0.30$ \\
\hline Waiampi/Asian & Amerindian & 78 & $70(89.7)$ & $8(10.3)$ & $0(0)$ & 0.05 & 0.260 & $0.80<\mathrm{p}<0.90$ \\
\hline Total & & 565 & 387 (68.5) & $153(27.1)$ & $25(4.4)$ & 0.18 & 3.912 & $0.10<\mathrm{p}<0.20$ \\
\hline
\end{tabular}


The frequency of 3'A mutation in Salvador samples is not consistent with other populations of predominantly African origin, reflecting the extensive African/European miscegenation in this population. The relatively high frequency of SDF1-3'A observed in Salvador samples can be attributed to admixture with European ancestry population, since this mutation is common in European but rare or absent in African populations. The low mutation frequency found in Waiampi tribe could also be explained by the interethnic admixture with non-Amerindian populations, even though, as it is found in Asian population, it may has been present in the ancestral population.

Although there is less information about the prevalence of this polymorphism in Brazilian population or about their impact as potential genetic biomarkers, the relative homogeneity in the frequency obtained support the earlier observations that the frequencies of SDF1-3'A mutation by itself may not be sufficient as a biomarker to determine the ancestry.

An understanding of the distribution of these frequencies in Brazilian ethnic groups could be important mainly because, together with others polymorphisms associated with HIV infection and AIDS progression, it will enable further comparative surveys among HIV-1 infected populations. Indeed, the detection of SDF1-3'A allelic frequency in the Brazilian population could give support to the improvement of methods to aid diagnosis, classification of disease status, and provide means to delineate therapeutic strategies.

\section{REFERENCES}

1. Deng H, Liu R, Ellmeier W et al. Identification of a major coreceptor for primary isolates of HIV-1. Nature 1996; 381:66166.

2. Mummidi S, Ahuja SS, Gonzalez E et al. Genealogy of the CCR5 locus and chemokine system gene variants associated with altered rates of HIV-1 disease progression.Nat.Med.1998; 4(7):786-93.

3. Berger EA, Murphy PM, Farber JM. Chemokine receptors as HIV-1 coreceptors: roles in viral entry, tropism, and disease. Annu. Rev. Immunol. 1999; 17:657-700.

4. Dragic T, Litwin V, Allaway GP et al. HIV-1 entry into CD4+ cells is mediated by the chemokine receptor CC-CKR-5. Nature 1996; 381(6584):667-73.

5. Grimaldi R, Shindo N, Acosta X et al. Prevalence of the CCR5Delta32 mutation in Brazilian populations and cell susceptibility to HIV-1 infection. Hum Genet. 2002; Jul; 111(1):102-4.

6. Liu H, Hwangbo Y, HolteS et al. Analysis of genetic polymorphisms in CCR5, CCR2, stromal cell-derived factor-1, RANTES, and dendritic cell-specific intercellular adhesion molecule-3grabbing nonintegrin in seronegative individuals repeatedly exposed to HIV-1. J Infect Dis. 2004; Sep 15; 190(6):1055-8. Epub 2004 Aug 2.

7. Modi WS, Scott K, Goedert JJ et al. Haplotype analysis of the SDF-1 (CXCL12) gene in a longitudinal HIV-1/AIDS cohort study. Genes Immun. 2005; Dec; 6(8):691-8.

8. Sei S, Boler AM, Nguyen GT et al. Protective effect of CCR5 delta 32 heterozygosity is restricted by SDF-1 genotype in children with HIV-1 infection. AIDS. 2001; Jul 27; 15(11):1343-52.
9. Winkler C, Modi W, Smith MW et al. Genetic restriction of AIDS pathogenesis by an SDF-1 chemokine gene variant. ALIVE Study, Hemophilia Growth and Development Study (HGDS), Multicenter AIDS Cohort Study (MACS), Multicenter Hemophilia Cohort Study (MHCS), San Francisco City Cohort (SFCC). Science. 1998; Jan 16; 279(5349):389-93.

10. Dezzutti CS, Guenthner PC, Green TA, Cohen OJ, Spira TJ, Lal RB. Stromal-derived factor- 1 chemokine gene variant is associated with the delay of HIV-1 disease progression in two longitudinal cohorts. AIDS. 2000; May 5; 14(7):894-6.

11. Cavalli-Sforza LL, Feldman MW. The application of molecular genetic approaches to the study of human evolution. Nat Genet. 2003; Mar; 33 Suppl:266-75.

12. Bamshad M, Wooding S, Salisbury BA, Stephens JC. Deconstructing the relationship between genetics and race. Nat Rev Genet. 2004; Aug; 5(8):598-609.

13. Rosenberg NA, Mahajan S, Ramachandran S, Zhao C, Pritchard JK, Feldman MW. Clines, clusters, and the effect of study design on the inference of human population structure. PLoS Genet. 2005; Dec;1(6):e70. Epub 2005 Dec 9.

14. IBGE-Instituto Brasileiro de Geografia e Estatística 2000. Pesquisa Nacional de Amostragem por Domicílio - Censo http://www.ibge.gov.br

15. Azevedo ES, Fortuna CMM, Silva KMC. Spread and diversity of human population in Bahia, Brazil. Hum. Biol. 1982; 54:329341.

16. Dourado I, Barreto ML, Teixeira MG, Galvão-Castro B. HTLV-I in the general population of a Brazilian city with the highest seroprevalence. AIDS. Res.Hum.Retrov. 2001; 17(S1) P009.

17. Smith MW, Carrington M, Winkler C et al. CCR2 chemokine receptor and AIDS progression.Nat Med. 1997; Oct; 3(10):1052-3.

18. van Rij RP, Broersen S, Goudsmit J, Coutinho RA, Schuitemaker $\mathrm{H}$. The role of a stromal cell-derived factor-1 chemokine gene variant in the clinical course of HIV-1 infection. AIDS. 1998; Jun $18 ; 12(9):$ F85-90.

19. Vidal F, Peraire J, Domingo P et al. Chemokines and Long-Term Nonprogressor Study Group. Lack of association of SDF-1 3A variant allele with long-term nonprogressive HIV-1 infection is extended beyond 16 years.J Acquir Immune Defic Syndr. 2005; Nov 1; 40(3):276-9.

20. Watanabe MA, de Oliveira Cavassin GG, Orellana MD et al. SDF-1 gene polymorphisms and syncytia induction in Brazilian HIV-1 infected individuals. Microb. Pathog. 2003; Jul; 35(1):31-4.

21. De Pinho Lott Carvalhaes FA, Cardoso GL, Hamoy IG, Liu YT, Guerreiro JF. Distribution of CCR5-delta32, CCR2-64I, and SDF1-3A mutations in populations from the Brazilian Amazon region Hum Biol. 2004; Aug; 76(4):643-6.

22. Silva WA Jr, Bonatto SL, Holanda AJ et al. Mitochondrial genome diversity of Native Americans supports a single early entry of founder populations into America. Am J Hum Genet. 2002; 71(1):187-92.

23. Mousinho-Ribeiro RC, Pante-de-Sousa G, Melo dos Santos EJ, Guerreiro JF. Genetic relationships among native americans based on beta-globin gene cluster haplotype frequencies. Genet. Mol. Biol. 2003; 26, 3, 229-234.

24. Wang S, Lewis CM Jr, Jakobsson M, Ramachandran S, Ray N. Genetic Variation and Population Structure in Native Americans. PLoS Genet. 2007; 3(11):e185.

25. Zago MA, Silva Júnior WA, Tavella MH, Santos SE, Guerreiro JF, Figueiredo MS. Interpopulational and intrapopulational genetic diversity of Amerindians as revealed by six variable number of tandem repeats. Hum Hered. 1996; Sep-Oct; 46(5):274-89. 